\title{
A AND B ANTIGENS IN THE HUMAN EPIDERMIS ${ }^{1}$
}

\author{
BY D. NELKEN, J. GUREVITCH, AND Z. NEUMAN \\ (From the Department of Clinical Microbiology, The Hebrew University-Hadassah Medical \\ School and the Department of Surgery, Plastic Service, Hadassah University \\ Hospital, Jerusalem, Israel)
}

(Submitted for publication October 8, 1956; accepted January 17, 1957)

Several attempts to demonstrate the presence of $A$ and $B$ antigens in the human epidermis have been undertaken in the past, but with negative results $(1,2)$. Recently, Coombs, Bedford, and Rouillard (3) proved by the mixed agglutination method the existence of $A$ and $B$ group specific substances in epidermal cells.

In continuation of studies on the A and B antigens in the human cornea $(4,5)$ the presence of these antigens in the human epidermis was investigated.

The following is a report of this investigation.

\section{MATERIAL AND METHODS}

Thin split thickness skin was obtained by means of an electric dermatome from 19 patients, selected at random, who were admitted to the hospital for various skin grafting procedures. No differentiation was made between secretors and non-secretors. Part of this skin was used for skin grafting, the rest rinsed in physiological saline and despatched to the laboratory, completely immersed in a container full of saline. There the excised skin was cut to standard size, $3 \times 3 \mathrm{~cm}$. and washed 3 times in $200 \mathrm{ml}$. normal saline. The flask containing saline and skin was agitated vigorously on a Kahn shaking machine for 10 minutes. In order to test for complete removal of erythrocytes, the last saline washing was centrifuged in large conical tubes and the minute sediments examined microscopically for red blood cells. If only one erythrocyte was found, three additional washings were carried out. Every sediment was further tested by the Benzidine Reaction (6). This was sometimes found to be positive after the first washing, but always negative after the third. After this treatment the skin was used either fresh or frozen at $-20^{\circ} \mathrm{C}$ in $2 \mathrm{ml}$. of normal saline. For every experiment $0.5 \times 0.5 \mathrm{~cm}$. pieces of skin were cut into very thin slices with the aid of fine scissors and scalpels. These slices were homogenized for $\mathbf{3 0}$ minutes in a small pyrex glass tissue grinder with a pyrex glass pestle connected to a variable speed stirring apparatus. Five-tenths $\mathrm{ml}$. of saline was added to the homogenate during homogenization. To prevent excessive heat production the grinder was immersed in

1 This study was aided by a grant from the Hematology Research Foundation, Chicago. an ice bath and the stirring carried out at intervals. The fine white pasty mass obtained served as antigenic material.

Preparation of sera. Sera were inactivated at $56^{\circ} \mathrm{C}$ for 30 minutes, and titrated for anti-A and anti-B isoagglutinins. Only sera with the minimal titer of $1: 128$ when undiluted were used for absorption experiments. Sera were distributed in small quantities stored at $-20^{\circ} \mathrm{C}$ until used; no serum was frozen and thawed more than once.

Isoagglutinin determination. Titrations of isoagglutinins were performed by the double serial dilution method against freshly prepared 2 per cent erythrocyte suspensions. Results were read after allowing the tubes to stand at room temperature for 30 minutes. The titer was expressed as the last dilution at which agglutinates could be detected by the naked eye. The tubes were neither centrifuged nor examined microscopically. All titrations were performed by the same technician, and the results read separately by two different persons (D. N. and J. G.). Changes in the intensity of agglutination were not taken as an indication for a reduction in titer, only the complete disappearance of agglutination was assumed to prove real absorption.

\section{EXPERIMENTAL PROCEDURES AND RESULTS}

\section{Absorption experiments}

Absorption experiments were performed in siliconized tubes to prevent the adherence of epidermal material to the glass. Five-tenths ml. of the homogenate was added to $0.5 \mathrm{ml}$. of hightitred $A, B$ or $O$ serum. Undiluted sera or sera diluted with normal saline in a proportion of $1: 1$ were used in the absorption experiments. The skin serum mixture was left for 8 hours at a temperature of $6^{\circ} \mathrm{C}$ and was shaken every 30 minutes. After 8 hours the serum was separated by centrifugation at 3,000 r.p.m. for 10 minutes.

Nineteen absorption experiments were performed with split skin homogenates from individuals of blood groups $A, B, O$ and $A B, 4,3,6$ and 6 instances of each, respectively. When $O$ serum was absorbed by epidermal homogenates from a donor of blood group $\mathrm{A}$ or from a donor 
TABLE I

Results of absorption and elution experiments

\begin{tabular}{|c|c|c|c|c|c|}
\hline \multirow{2}{*}{$\begin{array}{c}\begin{array}{c}\text { Experi- } \\
\text { ment } \\
\text { No. }\end{array} \\
1\end{array}$} & \multicolumn{2}{|c|}{$\begin{array}{l}\text { Titer of serum } 0 \\
\text { before absorption }\end{array}$} & \multirow{2}{*}{$\begin{array}{c}\begin{array}{c}\text { Epidermal } \\
\text { material } \\
\text { from } \\
\text { donor of } \\
\text { blood } \\
\text { group }\end{array} \\
\text { A }\end{array}$} & \multirow{2}{*}{$\begin{array}{c}\begin{array}{c}\text { Titer of } \\
\text { serum O } \\
\text { after one ab- } \\
\text { 8orption with } \\
\text { epidermal } \\
\text { homogenate }\end{array} \\
1: 64 \\
1: 256\end{array}$} & \multirow{2}{*}{$\begin{array}{c}\begin{array}{c}\text { Titer of } \\
\text { eluate } \\
\text { against red } \\
\text { blood cells }\end{array} \\
1: 8 \\
0\end{array}$} \\
\hline & $\begin{array}{l}\text { Anti-A } \\
\text { Anti-B }\end{array}$ & $\begin{array}{l}1: 128 \\
1: 256\end{array}$ & & & \\
\hline 2 & $\begin{array}{l}\text { Anti-A } \\
\text { Anti-B }\end{array}$ & $\begin{array}{l}1: 128 \\
1: 256\end{array}$ & A & $\begin{array}{l}1: 64 \\
1: 256\end{array}$ & $1: 8$ \\
\hline 3 & $\begin{array}{l}\text { Anti-A } \\
\text { Anti-B }\end{array}$ & $\begin{array}{l}1: 64 \\
1: 128\end{array}$ & A & $\begin{array}{l}1: 16 \\
1: 128\end{array}$ & $\begin{array}{c}1: 4 \\
0\end{array}$ \\
\hline 4 & $\begin{array}{l}\text { Anti-A } \\
\text { Anti-B }\end{array}$ & $\begin{array}{l}1: 64 \\
1: 128\end{array}$ & A & $\begin{array}{l}1: 8 \\
1: 128\end{array}$ & $\begin{array}{c}1: 8 \\
0\end{array}$ \\
\hline 5 & $\begin{array}{l}\text { Anti-A } \\
\text { Anti-B }\end{array}$ & $\begin{array}{l}1: 128 \\
1: 256\end{array}$ & B & $\begin{array}{l}1: 128 \\
1: 128\end{array}$ & $\begin{array}{c}0 \\
1: 16\end{array}$ \\
\hline 6 & $\begin{array}{l}\text { Anti-A } \\
\text { Anti-B }\end{array}$ & $\begin{array}{l}1: 64 \\
1: 128\end{array}$ & B & $\begin{array}{l}1: 64 \\
1: 32\end{array}$ & $\begin{array}{c}0 \\
1: 8\end{array}$ \\
\hline 7 & $\begin{array}{l}\text { Anti-A } \\
\text { Anti-B }\end{array}$ & $\begin{array}{l}1: 64 \\
1: 128\end{array}$ & B & $\begin{array}{l}1: 64 \\
1: 32\end{array}$ & $\begin{array}{c}0 \\
1: 4\end{array}$ \\
\hline 8 & $\begin{array}{l}\text { Anti-A } \\
\text { Anti-B }\end{array}$ & $\begin{array}{l}1: 128 \\
1: 256\end{array}$ & $\mathrm{AB}$ & $\begin{array}{l}1: 64 \\
1: 128\end{array}$ & $\begin{array}{l}1: 8 \\
1: 4\end{array}$ \\
\hline 9 & $\begin{array}{l}\text { Anti-A } \\
\text { Anti-B }\end{array}$ & $\begin{array}{l}1: 128 \\
1: 256\end{array}$ & $\mathrm{AB}$ & $\begin{array}{l}1: 32 \\
1: 128\end{array}$ & $\begin{array}{l}1: 4 \\
1: 4\end{array}$ \\
\hline 10 & $\begin{array}{l}\text { Anti-A } \\
\text { Anti-B }\end{array}$ & $\begin{array}{l}1: 64 \\
1: 128\end{array}$ & $\mathrm{AB}$ & $\begin{array}{l}1: 16 \\
1: 64\end{array}$ & $\begin{array}{l}1: 2 \\
1: 2\end{array}$ \\
\hline 11 & $\begin{array}{l}\text { Anti-A } \\
\text { Anti-B }\end{array}$ & $\begin{array}{l}1: 64 \\
1: 128\end{array}$ & $\mathrm{AB}$ & $\begin{array}{l}1: 16 \\
1: 64\end{array}$ & $\begin{array}{l}1: 2 \\
1: 2\end{array}$ \\
\hline 12 & $\begin{array}{l}\text { Anti-A } \\
\text { Anti-B }\end{array}$ & $\begin{array}{l}1: 64 \\
1: 128\end{array}$ & $\mathrm{AB}$ & $\begin{array}{l}1: 16 \\
1: 32\end{array}$ & $\begin{array}{l}1: 4 \\
1: 2\end{array}$ \\
\hline 13 & $\begin{array}{l}\text { Anti-A } \\
\text { Anti-B }\end{array}$ & $\begin{array}{l}1: 64 \\
1: 128\end{array}$ & $\mathrm{AB}$ & $\begin{array}{l}1: 32 \\
1: 16\end{array}$ & $\begin{array}{l}1: 4 \\
1: 4\end{array}$ \\
\hline 14 & $\begin{array}{l}\text { Anti-A } \\
\text { Anti-B }\end{array}$ & $\begin{array}{l}1: 128 \\
1: 256\end{array}$ & 0 & $\begin{array}{l}1: 128 \\
1: 256\end{array}$ & $\begin{array}{c}0 \\
1: 1\end{array}$ \\
\hline 15 & $\begin{array}{l}\text { Anti-A } \\
\text { Anti-B }\end{array}$ & $\begin{array}{l}1: 64 \\
1: 128\end{array}$ & 0 & $\begin{array}{l}1: 64 \\
1: 128\end{array}$ & $\begin{array}{l}0 \\
0\end{array}$ \\
\hline 16 & $\begin{array}{l}\text { Anti-A } \\
\text { Anti-B }\end{array}$ & $\begin{array}{l}1: 64 \\
1: 128\end{array}$ & 0 & $\begin{array}{l}1: 64 \\
1: 128\end{array}$ & $\begin{array}{l}0 \\
0\end{array}$ \\
\hline 17 & $\begin{array}{l}\text { Anti-A } \\
\text { Anti-B }\end{array}$ & $\begin{array}{l}1: 64 \\
1: 128\end{array}$ & 0 & $\begin{array}{l}1: 64 \\
1: 128\end{array}$ & $\begin{array}{l}0 \\
0\end{array}$ \\
\hline 18 & $\begin{array}{l}\text { Anti-A } \\
\text { Anti-B }\end{array}$ & $\begin{array}{l}1: 64 \\
1: 128\end{array}$ & 0 & $\begin{array}{l}1: 64 \\
1: 128\end{array}$ & $\begin{array}{l}0 \\
0\end{array}$ \\
\hline 19 & $\begin{array}{l}\text { Anti-A } \\
\text { Anti-B }\end{array}$ & $\begin{array}{l}1: 64 \\
1: 128\end{array}$ & 0 & $\begin{array}{l}1: 64 \\
1: 128\end{array}$ & $\begin{array}{l}\mathbf{0} \\
\mathbf{0}\end{array}$ \\
\hline
\end{tabular}

of blood group B, only the titer of the corresponding isoagglutinin was reduced, while that of the other agglutinin remained unchanged. When $\mathrm{O}$ sera were absorbed by epidermal homogenates of
$A B$ donors, absorption of both anti-A and anti-B isoagglutinins occurred. Similar results were obtained when A and B sera were absorbed by epidermal homogenates of the corresponding group. When epidermal material of group $\mathrm{O}$ donors was used for the absorption experiments, no reduction whatsoever could be detected in either the anti-A or anti-B titer of the absorbed serum (see Table I).

In three cases, repeated absorptions were performed with epidermal material from individuals of the same blood group. After three consecutive absorptions the titer of the antiserum was reduced from $1: 128$ to $1: 4$.

Table II summarizes the results of one such repeated absorption experiment.

\section{Elution experiments}

Eluates were prepared from the homogenates which served for the absorption experiments. The absorbates were washed three times in large amounts of saline to ensure removal of traces of serum. The washed epidermal sediment was resuspended in $0.4 \mathrm{ml}$. of normal saline and vigorously shaken by hand in a water bath of $56^{\circ} \mathrm{C}$ for 5 minutes. It was then centrifuged at 3,000 r.p.m. for 1 minute in cups jacketted with water at $56^{\circ} \mathrm{C}$ and the eluate was immediately removed. Using the above technique, eluates of 19 different samples of split skin homogenates were prepared and examined for agglutinating capacity against erythrocytes. In all cases eluates agglutinated erythrocytes of the corresponding group.

Results of absorption and elution experiments are summarized in Table I. Apart from the quantitative reduction of the titer a marked difference in the intensity of agglutination in the last two to three tubes of the titrations was observed.

\section{DISCUSSION}

Recent studies on skin homografts have established the fact that human epidermis is antigenic and may induce the production of antibodies (1, 7-10). The question of which antigens are concerned in the homograft reaction is still unsettled.

The possible existence of $A$ and $B$ antigens in human epidermis was studied for the first time in 1928 by Yosida (2), with negative results. Medawar (11) in 1946 examined the possibility that a 
TABLE II

Results of three consecutive absorptions of $A$ serum with epidermis of an individual of blood group $B$

\begin{tabular}{lcccccccc}
\hline \hline \multicolumn{1}{c}{ Titer of serum } & $1: 1$ & $1: 2$ & $1: 4$ & $1: 8$ & $1: 16$ & $1: 32$ & $1: 64$ & $1: 128$ \\
\hline Before absorption & +++ & +++ & +++ & +++ & +++ & ++ & + & \pm \\
After first absorption & +++ & +++ & +++ & ++ & ++ & \pm & - & - \\
After second absorption & +++ & +++ & ++ & + & - & - & - \\
After third absorption & ++ & + & \pm & - & - & - & - \\
\hline
\end{tabular}

prior blood transfusion leads to immunity to skin grafts from the same animal. He also investigated the question of whether the transplantation of homologous skin results in the formation of red cell agglutinins. He could not demonstrate an antigenic relationship between erythrocytes and epidermis. In 1954, Co Tui, Campbell, Rothburd, and Fand (1) studied the same problem with the aid of tissue cultures. They used skin cultures from human donors of $A$ and $B$ blood groups and treated them with antisera; they were, however, unable to observe morphologic changes in the explants.

Recently, Coombs, Bedford, and Rouillard (3) demonstrated, by mixed agglutination between erythrocytes and epidermal cells, that human epidermal cells possess $A$ and $B$ antigens. Gorer (12) mentions the finding of immune anti-A antibodies in two patients after skin grafting. Clarkson and Gorer (13) reported a case of a burnt child who, following a skin homograft, developed immune anti-erythrocyte antibodies. Pfeffer and Rogers (14) stated that they observed less violent rejections of the homotransplanted skin grafts when using homografts from donors of compatible blood groups.

In the present investigation the existence of $\mathrm{A}$ and $B$ antigens has been established by absorption and elution methods. Split skin homogenates from individuals of blood groups $A$ and $B$ reduced the titer of anti-A and anti-B sera. The eluates prepared from these homogenates agglutinated red blood cells of the corresponding group. It may be assumed that the presence of $\mathrm{A}$ and $\mathrm{B}$ antigens in the human epidermis will be of importance in skin homografting.

\section{SUMMARY}

Human epidermis was found to contain $\mathrm{A}$ and B blood group antigens corresponding to those of red blood cells.

\section{REFERENCES}

1. Co Tui, Campbell, R. M., Rothburd, M., and Fand, I., Failure to demonstrate skin groups analogous to blood groups using human skin cultures. Proc. Soc. Exper. Biol. \& Med., 1954, 85, 398.

2. Yosida, K.-I., Utber die gruppenspezifischen Unterschiede der Transsudate, Exsudate, Sekrete, Exkrete, Organextrakte und Organzellen des Menschen und ihre rechtsmedizinischen Anwendungen. Ztschr. f. d. ges. exper. Med., 1928, 63, 331 (as cited by Coombs, R. R. A., Lancet, 1956, 1, 461).

3. Coombs, R. R. A., Bedford, D., and Rouillard, L. M., $A$ and $B$ blood-group antigens on human epidermal cells demonstrated by mixed agglutination. Lancet, 1956, 1, 461.

4. Nelken, E., Michaelson, I. C., Nelken, D., and Gurevitch, J., $\mathrm{ABO}$ antigens in the human cornea. $\mathrm{Na}$ ture, 1956, 177, 840.

5. Nelken, E., Michaelson, I. C., Nelken, D., and Gurevitch, J., Studies on antigens in the human cornea and their relationship to corneal grafting in man. J. Lab. \& Clin. Med., In press.

6. Gradwohl, R. B. H., Clinical Laboratory Methods and Diagnosis. St. Louis, The C. V. Mosby Co., 1943, Vol. I, p. 831 .

7. Billingham, R. E., and Sparrow, E. M., Studies on the nature of immunity to homologous grafted skin, with special reference to the use of pure epidermal grafts. J. Exper. Biol., 1954, 31, 16.

8. Dempster, W. J., Problems involved in the homotransplantation of tissues with particular reference to skin. Brit. M. J., 1951, II, 1041.

9. Medawar, P. B., The behaviour and fate of skin autografts and skin homografts in rabbits. J. Anat., 1944, 78, 176.

10. Medawar, P. B., A second study of the behaviour and fate of skin autografts in rabbits. J. Anat., 1945, 79, 157.

11. Medawar, P. B., Relationship between the antigens of blood and skin. Nature, 1946, 157, 161.

12. Gorer, P. A., The antibody response to skin homografts in mice. Ann. New York Acad. Sc., 1955, 59,365 .

13. Clarkson, P., and Gorer, P., Development in a burnt child of antibodies following skin homografts. Proc. Roy. Soc. Med., 1956, 49, 117.

14. Pfeffer, A. Z., and Rogers, B. O., The possible role of blood group antigens in the behaviour of skin homografts. Plast. \& Reconstruct. Surg., 1955, 15, 459. 